\title{
Merkel Cell Carcinoma cN2 TNM Finding v7
}

National Cancer Institute

\section{Source}

National Cancer Institute. Merkel Cell Carcinoma cN2 TNM Finding v7. NCI Thesaurus.

Code $C 88546$.

Merkel cell carcinoma in transit metastasis. In transit metastasis is defined as a tumor distinct from the primary lesion and located either (1) between the primary lesion and the draining regional lymph nodes or (2) distal to the primary lesion. (from AJCC 7th Ed.) 